\title{
FINANCIAL INVESTMENT IN THE REPUBLIC OF UZBEKISTAN: CONCEPT, OBJECTIVES, ACCOUNTING AND REPORTING
}

\author{
SAIDJAMOL MAHMUDOV
}

Andijan Engineer Economic Institute, Uzbekistan

\begin{abstract}
The concept of economic essence of financial investments has been defined. Recommendations on improving accounting of long-term and short-term securities have been worked out. Necessity of improving securities accounting, their reflection in the financial reporting, organization of accounting reporting in the part of financial investments accounting has been highlighted. Analytical accounting on the accounts of long-term investments accounting (0600) is conducted on the types of long-term investments and objects, in which these investments are made. Correspondingly compilation of analytical accounting must provide possibility of receiving data about long-term investments in the objects located in the territory of Uzbekistan and outside it. Financial placements are accepted for accounting as the sum of actual costs for an investor.
\end{abstract}

\section{JEL CLASSIFICATION \& KEYWORDS}

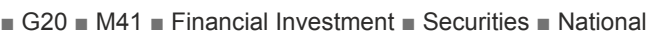
Accounting Standards $\approx$ Shares ॥ International Accounting Standards = Actual Cost of Financial Investments a Long-term

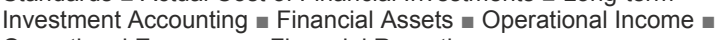
Operational Expenses a Financial Reporting.

\section{INTRODUCTION}

At present time the problem of post-crisis recovery of the economy is one of the crucial for many countries all over the world. The significance of this issue has been stated by the president of the Republic of Uzbekistan I. A. Karimov: "Continuing replenishing of the market by huge money funds at the significant increase of the share of bad and nonperforming loans as well as insufficient control over the activity of banking and financial sector create conditions for speculative capital expansion, making bubbles on the stock exchange and commodity exchange which can lead to new collapses on the stock and commodity market with all consequences" [1]. Taking this statement into consideration it is possible to make a conclusion that the scales of the state budget deficits and the principals are quite large and in some countries are even threatening. It, in turn, leads to the overstrain of the financial sector, restriction of expenses and reduction of the demand on the both domestic and foreign markets. Being very important, a securities market is considered to be a sphere of intensive control and regulation by the government.

\section{Main part}

Securities accounting is one of the forms of the control. With this aim an accounting policy of companies or enterprises is compiled and confirmed at the beginning of the year. What is necessary to be reflected in the accounting policy on the securities issues?

We have grouped different opinions on the accounting policy for the purpose of financial investments accounting.

Taking into consideration data from the table it is possible to make a conclusion that a more detailed reflection of securities accounting has been given by the author and he considers all aspects of indicators of securities accounting. www.journals.cz/
Another issue is their reflection on the corresponding accounts.

Table 1: Opinions on the accounting policy on the financial investments accounting

\begin{tabular}{|c|c|c|c|c|c|c|}
\hline Opinions & [1] & [2] & [3] & [4] & [5] & [6] \\
\hline $\begin{array}{l}\text { Way of assessing financial investments at } \\
\text { their disposal in groups; }\end{array}$ & "+" & "+" & "+" & "+" & "+" & "+" \\
\hline $\begin{array}{l}\text { Changes of ways of financial investments } \\
\text { assessment at their disposal; }\end{array}$ & "-" & "-" & "-" & "-" & "-" & "+" \\
\hline $\begin{array}{l}\text { Present market value and financial } \\
\text { investments at which current market value } \\
\text { is not defined; }\end{array}$ & "+" & "-" & "-" & "+" & "-" & "+" \\
\hline $\begin{array}{l}\text { Difference between present market value } \\
\text { on the reporting date and trial assessment } \\
\text { of financial investments; }\end{array}$ & "-" & "+" & "-" & "-" & "-" & "+" \\
\hline $\begin{array}{l}\text { Difference between an initial cost of debt } \\
\text { securities on which present market value } \\
\text { has not been defined during the period of } \\
\text { their circulation; }\end{array}$ & "-" & "-" & "-" & "-" & "+" & "+" \\
\hline & "-" & "+" & "+" & "-" & "-" & "+" \\
\hline $\begin{array}{l}\text { Value and types } \\
\text { other financial inv } \\
\text { other organizatior } \\
\text { selling); }\end{array}$ & "+" & "-" & "-" & "+" & "-" & "+" \\
\hline $\begin{array}{l}\text { epreciation of } \\
\text { reference of }\end{array}$ & "+" & "-" & "-" & "-" & "-" & "+" \\
\hline $\begin{array}{l}\text { Data on the debt securit } \\
\text { about discounted value }\end{array}$ & "-" & "+" & "+" & "-" & "-" & "+" \\
\hline \multicolumn{7}{|c|}{$\begin{array}{l}\text { [1] International financial reporting standards: textbook. Edited by M. } \\
\text { Vahrushina:Omega-L, 2007.-568p. -p.31-33. } \\
\text { [2] Kovalev A. Preparation and analysis of separate and consolidated } \\
\text { reporting on the IFRS with the help of "1C:Consolidation 8".-M.:OO "1 C - } \\
\text { Publishing, S-Petersburg, 2008.-536p. P.21-26 } \\
\text { [3] Rayhan B. Strategic accounting for manager/Edited by Mikryukov V. } \\
\text {.M.: audit,yuniti, 1998.-616p. P.52-54. } \\
\text { [4] Blake J., Amat O. European accounting. -M. "Filin", 1997.-400p. P. 21- } \\
24 \text {. } \\
\text { [5] Rizayev N. Issues of formation accounting policy on the basis of IFRS.// } \\
\text { "Problems of improving fiscal policy in conditions of the economy } \\
\text { modernization and diversification . Materials of the conference held in the } \\
\text { Tax academy of the Republic of Uzbekistan. 2010., p 276-278. } \\
\text { [6] Author's opinion }\end{array}$} \\
\hline
\end{tabular}

Source: Author

According to the national accounting standards of the Republic of Uzbekistan summarizing the information about presence and movement of short-term (less than 1 year) investments (placements) of enterprises in the securities of other enterprises, government bonds, loans given to enterprises, etc. are carried out on the following accounts:

5810-«Securities»;

5830- «Short-term loans given»;

5890-«Other operating investment».

Financial investments with the maturity of more than 1 year are accounted on the following accounts:

0610 «Securities»;

0620 «Investment in economic subsidiaries»;

0630 «Investment in the dependant economic entities»; 0640 «Investment in the capital with foreign capital»; 0690 «Other long-term investments». 
Analytical accounting on the accounts of short-term investments accounting (5800) is carried out on the types of short-term investment and objects in which these placements have been performed (enterprises - securities sellers, deposits, etc.).

The order of referring assets to investment and their types are regulated by the national accounting standards of the Republic of Uzbekistan: (NAS 12) "Financial investments accounting" confirmed by the Ministry of Finance of the Republic of Uzbekistan dated from December 25, 1998 № 65 (registered № 596 from January 16, 1999 - "Bulletin of normative acts", 1999, № 3 and № 6) and (NAS № 8) "Consolidated financial reports and investments accounting in the subsidized economic entities», confirmed by the Ministry of Finance of the Republic of Uzbekistan from October 14, 1998 № 50 (registered № 580 from December 28, 1998 - "Bulletin of normative acts", 1999, № 6).

Shares, bonds and other securities are accounted on the debit of the accounts 0610 "Securities" at the purchase value in the correspondence with the accounts on which valuables submitted at the expense of these placements are accounted.

The next issue is reflection of the difference between a nominal and an actual value of the share.

First of all, it is necessary to analyze releases of shares and a number of joint-stock companies.

Figure 1: Correlation of the number of joint-stock companies to the total volume of shares release in 2001-2009

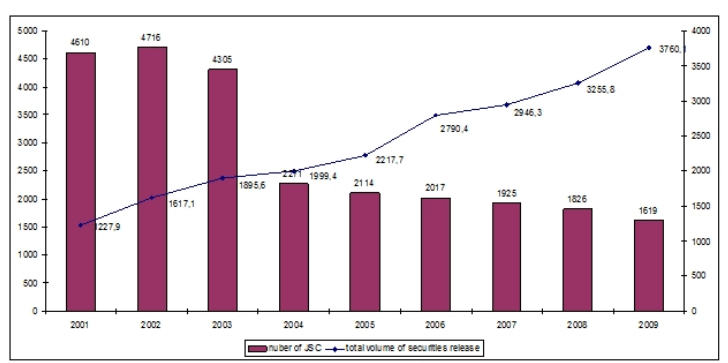

Source: Butikov I. (2008) and Almanac Uzbekistan 2010

Some scientists have referred it to the results of financial and economic activity of the company, i.e. if a purchase value of the shares acquired by the enterprise is higher than their nominal value and in this case during the whole period since their purchase till the maturity there is conducted a write-off of the part of the difference between a purchase value and a nominal value. If a purchase value of the shares acquired by the enterprise is lower than their nominal value, in this case during the whole period since their purchase till the maturity there is conducted a crediting additional amount of the part of the difference between a purchase value and a nominal value. Another group of scientists referred them to operational expenses. However, in our opinion, cost of shares, accounted on the "Securities" account must comply with their nominal value. Therefore, by the share maturity, the assessment, in which they are accounted on the "Securities" account, must comply with their nominal value. Financial investments are accepted to the accounting in the form of the sum of actual costs of the investor. What can be considered as actual costs of securities acquire?

In our opinion, actual costs for acquiring securities can be the following: sums paid to the seller in accordance with an agreement; sums paid to the specialized organizations and other entities for information and consulting services connected with securities purchase; remunerations paid to www.journals.cz/ the intermediary entities with which participation securities are acquired; expenses on the interest payment on borrowings used on acquiring securities before accepting them to the accounting; other expenses directly connected with securities purchase.

Expenses connected with the release and distribution of securities are reflected on the debit of account «Expenditures on the release and distribution of securities» in correspondence with accounts of liabilities and cash accounting. Data about long-term and short-term financial placements at the beginning and at the end of the reporting year on their main types (shares and stocks of organizations, bonds and other debt liabilities, loans given, other financial placements) are presented in the accounting balance.

Besides, the report about cash flow contains information about receiving funds on dividends and interest on financial placements and funds expenditures on the payment of dividends and interest on securities.

Information on interests receivable and payments and income from economic entities is contained in chapter II "Operational income and expenditures" of the Income Statement (form N 2).

\section{Conclusion}

In conditions of the innovation economy development tools and aims of investing significantly differ. Such securities, as swaps, derivatives, options and futures are becoming more popular.

Taking into consideration requirements of international standards of financial reporting, in our opinion, it is recommended to offer the following technique of assessment in transformed reporting of financial assets. According to it, if a company can't get the principal and interests according to the negotiated conditions of the loan, there can be loss from devaluation. Amount of loss is defined as difference between accounting cost of the asset and its market value, i.e. present value of expected cash flow discounted with application of the efficient interest rate on the financial assets.

\section{REFERENCES}

1. Karimov I.A. On the way of overcoming consequences of the world crisis, country modernization and obtaining the level of developed countries. - T.: «Uzbekistan, 2010. -V.18.-248p. P.232.

2. Butikov I. Stock market of Uzbekistan: problems of formation and development.-Tashkent:KONSAUDITINFORM-NASHR, 2008.224p. P.55.

3. International financial reporting standards: textbook. Edited by $M$. Vahrushina .-M.:Omega-L, 2007.-568p. -p.31-33.

4. Kovalev A. Preparation and analysis of separate and consolidated reporting on the IFRS with the help of «1C:Consolidation 8».M.:OO «1 C - Publishing, S-Petersburg, 2008.-536p. P.21-26

5. Rayhan B. Strategic accounting for manager/Edited by Mikryukov V. .-M.: AUDIT,YUNITI, 1998.-616p. P.52-54.

6. Blake J., Amat O., European accounting. -M. «Filin», 1997.-400p. P. 21-24.

7. Rizayev N. Issues of formation accounting policy on the basis of IFRS.// "Problems of improving fiscal policy in conditions of the economy modernization and diversification . Materials of the conference held in the Tax academy of the Republic of Uzbekistan. 2010., p 276-278.

8. Almanac Uzbekistan 2010. Tashkent, 2010. -168p. -P.88. 